\title{
PERSEPSI ANGGOTA GEREJA ATAS PENGENDALIAN INTERNAL
}

\section{Eka Adhi Wibowo* \& Heru Kristanto*}

\begin{abstract}
This study aims at analyzing differences in perceptions of church members (pastors, treasurers, and congregations) on internal control and the relationship between the amount of offerings and the church's perception of internal control. Respondents come from Protestant Christian churches in particular which are the supporting synods of Duta Wacana Christian University, Yogyakarta. They consist of 31 congregations with 92 people as respondents. The result of Kruskal Wallis statistic test shows that there is no difference of perception among the three members of the church about internal control. The Pearson correlation test results between the amount of offerings and the church member's perception of financial control is positive, but very low. The development of the amount of offerings is followed by internal control, albeit at low levels.
\end{abstract}

Keywords: perceptions of church members, internal control, Protestant Christian churches.

\section{Abstrak}

Penelitian ini bertujuan untuk menganalisis perbedaan persepsi anggota gereja (pendeta, bendahara, dan jemaat) tentang pengendalian internal dan hubungan antara jumlah persembahan dengan persepsi gereja terhadap pengendalian internal. Responden berasal dari Gereja-gereja Kristen Protestan khususnya yang menjadi sinode gereja pendukung Universitas Kristen Duta Wacana, Yogyakarta, sebanyak 31 jemaat dengan 92 orang

* Universitas Kristen Duta Wacana. Email: ekaadhiw@staff.ukdw.ac.id

** Universitas Kristen Duta Wacana. Email: heru1405@gmail.com 
sebagai responden. Hasil uji statistik Kruskal Wallis tidak terdapat perbedaan persepsi di antara ketiga anggota gereja tentang pengendalian internal. Hasil uji statistik korelasi Pearson antara jumlah persembahan dengan persepsi anggota gereja terhadap pengendalian keuangan adalah positif, tetapi sangat rendah. Perkembangan jumlah persembahan diikuti pengendalian internal, meskipun dengan kadar rendah.

Kata-kata kunci: persepsi anggota gereja, pengendalian internal, gereja-gereja Kristen Protestan.

\section{PENDAHULUAN}

Pertumbuhan organisasi nonprofit, termasuk organisasi keagamaan, semakin pesat. Sebagai organisasi nonprofit dalam bidang keagamaan, gereja mengalami pertumbuhan dalam jumlah umat dan sumber daya yang dimiliki. Kondisi ini menuntut akuntabilitas yang tinggi karena semakin besarnya dana publik (jemaat) yang dipercayakan untuk dikelola (Booth, 1993). Pernyataan Booth kemudian diperkuat oleh Blackwood (2012) bahwa organisasi nonprofit berkontribusi sebesar 5\% pada Pendapatan Domestik Bruto negara Amerika Serikat.

Gereja sebagai organisasi keagamaan berpengaruh signifikan pada kegiatan yang bersifat nonprofit di banyak negara dan cenderung memiliki kendali yang cukup besar pada sumber daya manusia, sumber daya keuangan dan sumber daya lain pada masyarakat, meskipun terjadi kecenderungan sekularisasi (Wilson, 1967). Namun demikian, pertumbuhan organisasi nonprofit dalam bidang keagamaan tersebut tidak diikuti dengan akuntabilitas yang tinggi. Salah satu akibat dari rendahnya akuntabilitas gereja tersebut adalah munculnya kasus-kasus penyimpangan keuangan (fraud) dalam organisasi gereja, bahkan diduga dilakukan oleh pemimpin, pengurus, maupun jemaat gereja sendiri.

Berdasarkan temuan Holfreter (2004), fraud pada organisasi nonprofit di Amerika Serikat terdeteksi sebesar US\$ 600 milliar, dengan 85\% data didominasi oleh organisasi keagamaan. Negara Indonesia yang dikenal sebagai negara yang religius ternyata juga tidak luput dari indikasi fraud pada organisasi religinya. Berdasarkan pemberitaan pada salah satu media, gereja sebagai organisasi nonprofit religi juga terindikasi penyimpangan keuangan sebesar $R p$ 4,7 triliun, yang diduga dilakukan oleh salah satu pendeta (www.jawaban.com). 
Kistler (2008) menemukan bahwa rendahnya akuntabilitas akan terwujud dalam penerapan pengendalian internal gereja, dan penerapan pengendalian internal akan tergantung dari persepsi individu dalam organisasi gereja terhadap pengendalian internal tersebut. Menurut Ellis (1974), gereja adalah organisasi nonprofit yang lemah pengendalian internalnya, karena sistem akuntansi yang tidak memadai dan kurang berkomitmen dengan manajemen keuangan. Hal ini membuat Midkitt (2004) menyampaikan pendapat bahwa, gereja dan organisasi nonprofit adalah sasaran utama terjadinya penyalahgunaan keuangan (fraud), dan fraud menjadi hal yang umum terjadi dalam gereja (Duncan dan Flesher, 2002).

Synder dan Clifton (2005) menyatakan bahwa gereja berada dalam risiko yang lebih besar dalam hal penyalahgunaan keuangan, karena sifat dari misi dan struktur manajemen yang cenderung memiliki sikap mengabaikan terhadap fraud (Comission on Private Philantrophy and Public Needs, 1975), serta gereja lebih sering menyembunyikan penyimpangan-penyimpangan keuangan (West dan Zech, 2007). Hasil survei Keller dan Owens, LLC (2015) salah satu akuntan publik yang melayani organisasi nonprofit khususnya gereja, melaporkan bahwa data pengendalian internal di banyak gereja adalah lemah dan tidak lengkap. Hal ini sangat menyedihkan, karena data tersebut digunakan oleh pengelola gereja, pemberi pinjaman, dan badan-badan pemerintah. Ketidaklengkapan dan keakuratan pelaporan keuangan, serta lemahnya pengendalian telah meningkatkan kecurangan keuangan, sehingga kondisi ini tidak dapat diterima oleh jemaat dan masyarakat. Akibat dari rendahnya akuntabilitas gereja tersebut adalah munculnya kasus-kasus fraud dalam organisasi gereja, bahkan diduga dilakukan oleh pemimpin, pengurus, maupun jemaat gereja sendiri.

Pelaksanaan suatu organisasi memerlukan pedoman-pedoman yang terarah untuk mencapai tujuannya. Demikian juga dengan gereja sebagai organisasi publik memerlukan pedoman-pedoman untuk mencapai tujuan. Pedoman tersebut hanya akan sekadar menjadi utopia jika tidak dilaksanakan oleh para penyelenggara atau pengurus organisasi gereja sebagaimana mestinya. Pengendalian internal mutlak diperlukan oleh organisasi gereja untuk memastikan pelaksanaan organisasi sesuai dengan pedoman pencapaian tujuan gereja serta meminimalkan penyimpangan-penyimpangan yang dapat mengakibatkan tujuan gereja tidak tercapai. Hal ini memerlukan pemahaman tentang pengendalian internal bagi para penyelenggara, pengelola, dan pengurus gereja.

Menurut Carmona dan Ezzamel (2006) rendahnya minat akademisi untuk mempelajari akuntansi pada lembaga keagamaan agak membingungkan, mengingat adanya keunggulan pengaruh lembaga keagamaan terhadap kehidupan dalam masyarakat, baik dalam bidang spiritual maupun ekonomi. Para akademisi menganggap bahwa gereja merupakan lembaga suci, sehingga mempunyai asumsi bahwa para penyelenggara gereja adalah orang-orang yang dapat dipercaya 
dan jujur, serta takut akan Tuhan. Namun dalam kenyataannya terdapat penyimpangan dalam mengelola persembahan di gereja, sehingga memerlukan pengendalian internal.

Pengendalian manajemen melalui pengendalian internal merupakan studi dalam konteks bisnis dan disepakati untuk dipraktikkan dalam pengelolaan keuangan pada lembaga gereja (Myers, 2012), yang lazim disebut sebagai isu pembagian sakral-sekular (Laughlin, 1984). Pembagian ini dipertimbangkan untuk meletakkan isu spiritual pada sisi lembaga nonprofit gereja (isu sakral dalam organisasi) dan sistem bisnis sekular yang keberadaannya mendukung kesakralan organisasi (Myers, 2012). Sistem pembagian ini untuk membedakan dengan isu inferioritas akuntansi dalam lembaga gereja yang sering mengabaikan pengendalian manajerial keuangan lembaga gereja (Booth, 1993). Kondisi ini sering diperumit dengan hubungan dan kewajiban non-kontraktual (sifatnya sukarela) ketika menyepakati persoalan keuangan (khususnya pekerja-pekerja relawan), dan kemitraan dalam hubungan dan kewajiban kemungkinan lebih ditekankan pada kebersamaan teologikal daripada persoalan keuangan (Laughlin, 1990; West dan Zech, 2007).

Uraian dan penjelasan di atas merupakan dasar pemikiran peneliti untuk melakukan pengujian mengenai persepsi organisasi gereja tentang pengendalian internal, serta menjelaskan kontribusi bagi gereja untuk mengelola keuangan dengan menerapkan pengendalian internal yang sesuai kaidah. Penelitian ini bertujuan untuk memahami perbedaan persepsi di antara para anggota gereja yang diwakili oleh individu-individu yang memegang peranan dalam organisasi gereja (pendeta, bendahara, dan jemaat) tentang pengendalian internal. Selain itu, penelitian ini juga berusaha menguji hubungan antara jumlah persembahan dengan persepsi para anggota gereja terhadap pengendalian internal.

\section{KAJIAN LITERATUR DAN PENGEMBANGAN HIPOTHESIS}

Menurut Booth (1993), penyembunyian kasus-kasus penyimpangan keuangan dalam gereja disebabkan oleh pandangan yang menganggap bahwa akuntabilitas adalah hal yang sekular. Gereja merupakan rumah Tuhan dan dianggap sebagai tempat suci atau sakral, tentu segala sesuatunya bekerja menurut kehendak Tuhan yang suci dan benar. Pandangan ini membuat akuntabilitas tidak layak berada dalam ranah gereja yang merupakan organisasi yang sakral atau dengan kata lain adanya akuntabilitas gereja akan menurunkan tingkat kesakralan gereja sebagai institusi religius. 
Konsep sakral dan sekular diperkenalkan pertama kali oleh Laughlin (1984), Laughlin menjabarkan konsep tersebut dari pemikiran gereja mengenai sakral dan duniawi (sacred and profane) yang menjadi dasar dalam sistem keyakinan religius (religious belief system), yang mempengaruhi persepsi individu atas penerapan akuntansi dalam gereja. Secara garis besar religious belief system digambarkan sebagai berikut:

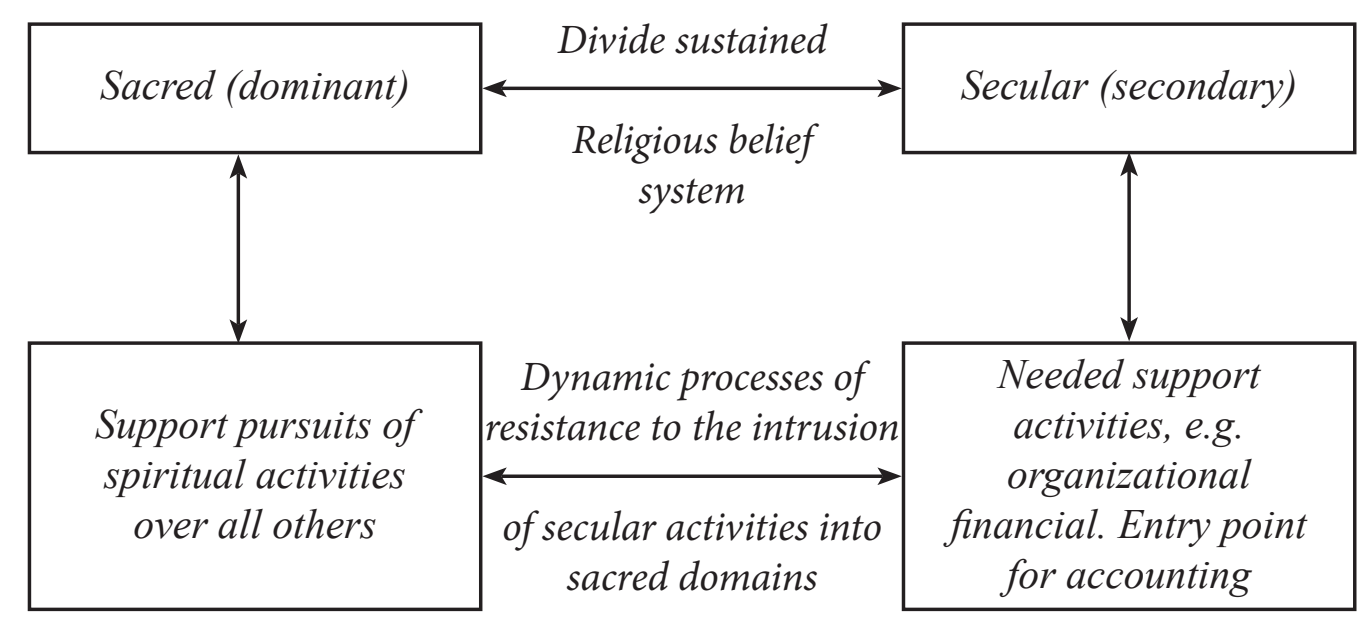

Gambar 1. Sacred and Secular Belief System (Laughlin, 1984)

Manfaat dari memahami belief tersebut adalah untuk mengetahui faktor utama yang menyebabkan penolakan atau penerimaan praktik akuntansi dalam organisasi gereja (Booth, 1993). Menurut Kistler (2008), dominasi keyakinan kesakralan (belief sacred dominant) akan berpotensi menimbulkan keyakinan buta (blind trust) pada pemimpin agama dan pengelola keuangan gereja. Penelusuran mengenai keyakinan buta kemudian dilakukan oleh Muller (2015) yang mengobservasi pemimpin gereja di negara berkembang dan menemukan bahwa pemimpin gereja di negara berkembang memiliki kecenderungan melakukan sakralisasi otoritas.

Menurut Booth (1993) terdapat faktor-faktor yang membagi belief tersebut, antara lain: (1) variasi interpretasi dalam jemaat gereja mengenai sakral dan sekular, (2) kelompok kerja yang berbeda dalam organisasi gereja, dan (3) keanggotaan dan keuangan. Ketiga faktor tersebut menurut Booth (1993) akan memengaruhi bagaimana akuntansi diterapkan dalam gereja, meskipun ketiga hal tersebut masih merupakan faktor umum. Booth (1993) menyatakan bahwa masih diperlukan analisa dan penelitian lebih lanjut untuk menemukan faktor-faktor lain, maupun observasi yang lebih mendalam karena kondisi gereja juga berbeda-beda satu dengan yang lain. Kompleksitas dari organisasi nonprofit inilah yang sering menjadikan organisasi nonprofit menjadi sasaran fraud, terlebih dalam organisasi gereja yang asetnya masih dikelola secara tradisional (Armacost, 1989). Pernyataan Armacost diperkuat oleh Duncan (1995) yang menemukan indikasi bahwa rata-rata 
organisasi gereja terlambat dalam menerapkan elemen-elemen pengendalian internal. Penelitianpenelitian tersebut menunjukkan bahwa pengendalian internal memiliki hubungan dengan fraud. Fenomena yang terjadi adalah fraud banyak terjadi dalam gereja.

Pengendalian internal telah didefinisikan secara luas sebagai suatu proses, dipengaruhi oleh dewan direksi entitas, manajemen, dan personel lainnya, yang dirancang untuk memberikan keyakinan yang memadai atas tercapainya tujuan mengenai aktivitas operasi, keandalan pelaporan keuangan dan kepatuhan terhadap peraturan yang berlaku (Committee of Sponsoring Organizations, 1992). Menurut Keister (1974), pengendalian internal didefinisikan sebagai alat dan proses yang digunakan untuk menjaga dan melestarikan aset organisasi. Zack (2003) menyatakan bahwa pengendalian internal adalah berbagai prosedur yang diadopsi oleh suatu organisasi untuk menjaga aset. Fokus utama pengendalian internal adalah pada penerimaan dan pengeluaran kas (Prentice, 1981). Pengendalian internal juga merupakan komponen penting dalam menyeimbangkan antara anggaran dan pelaksanaan misi pelayanan gereja, hanya saja sering terjadi konflik dalam hal kesakralan misi pelayanan dengan akuntansi yang dianggap sekular (Irvine, 2005). Lebih lanjut menurut Irvine (2005) menemukan bahwa persepsi tersebut dipengaruhi oleh latar belakang pengetahuan seseorang yang juga dapat menjadi salah satu faktor penentu jabatan dalam kepengurusan organisasi gereja.

Tuhan Yesus Kristus sendiri menegaskan pentingnya pengendalian internal dalam suatu ilustrasi yang tertulis dalam Injil Lukas 16:1-13 sebagai berikut:

Dan Yesus berkata kepada murid-muridNya: "Ada seorang kaya yang mempunyai seorang bendahara. Kepadanya disampaikan tuduhan bahwa bendahara itu menghamburkan miliknya. Lalu ia memanggil bendahara itu dan berkata kepadanya: Apakah yang kudengar tentang engkau? Berilah pertanggungan jawab atas urusanmu, sebab engkau tidak boleh lagi bekerja sebagai bendahara. Kata bendahara itu di dalam hatinya: Apakah yang harus aku perbuat? Tuanku memecat aku dari jabatanku sebagai bendahara. Mencangkul aku tidak dapat, mengemis aku malu. Aku tahu apa yang akan aku perbuat, supaya apabila aku dipecat dari jabatanku sebagai bendahara, ada orang yang akan menampung aku di rumah mereka. Lalu ia memanggil seorang demi seorang yang berhutang kepada tuannya. Katanya kepada yang pertama: Berapakah hutangmu kepada tuanku? Jawab orang itu: Seratus tempayan minyak. Lalu katanya kepada orang itu: Inilah surat hutangmu, duduklah dan buat surat hutang lain sekarang juga: Lima puluh tempayan. Kemudian ia berkata kepada yang kedua: Dan berapakah hutangmu? Jawab orang itu: Seratus pikul gandum. Katanya kepada orang itu: Inilah surat hutangmu, buatlah surat hutang lain: Delapan puluh pikul. Lalu tuan itu memuji bendahara yang tidak jujur itu, karena ia telah bertindak dengan cerdik. Sebab anak-anak dunia ini lebih cerdik terhadap sesamanya dari pada anak-anak terang. Dan Aku berkata kepadamu: Ikatlah persahabatan dengan mempergunakan Mamon yang tidak jujur, supaya jika Mamon itu tidak dapat menolong lagi, kamu diterima di dalam kemah abadi. "Barangsiapa setia dalam perkara-perkara kecil, ia setia juga dalam perkara-perkara besar. Dan barangsiapa tidak benar dalam perkara-perkara kecil, ia tidak benar juga dalam perkara-perkara besar. Jadi, jikalau kamu tidak setia dalam hal Mamon yang tidak jujur, siapakah yang akan mempercayakan kepadamu harta yang 
sesungguhnya? Dan jikalau kamu tidak setia dalam harta orang lain, siapakah yang akan menyerahkan hartamu sendiri kepadamu? Seorang hamba tidak dapat mengabdi kepada dua tuan. Karena jika demikian ia akan membenci yang seorang dan mengasihi yang lain, atau ia akan setia kepada yang seorang dan tidak mengindahkan yang lain. Kamu tidak dapat mengabdi kepada Allah dan kepada Mamon.

Dalam ilustrasi tersebut, Yesus menegaskan bahwa pengendalian internal yang lemah akan berpotensi menimbulkan penyalahgunaan kekuasaan. Pentingnya pengendalian internal tersebut dipertegas oleh Rasul Paulus dalam melakukan pengiriman dana bantuan dari Korintus ke Yerusalem dengan disertai seorang pengawas untuk membuktikan kejujurannya (2 Kor. 8:1822). Konsep pemberian kepada Tuhan dan konsep pengendalian internal ternyata sama-sama terdapat dalam Alkitab. Pendekatan yang dilakukan oleh Booth (1993) menganalisa penerapan pengendalian internal dari belief yang dianut. Penelitian ini mencoba melakukan pendekatan dari dua sisi, pengetahuan dan belief karena kedua hal tersebut saling memengaruhi satu sama lain dalam menentukan sikap tiap-tiap individu terhadap pengendalian internal.

Jabatan yang diampu oleh seseorang dalam gereja dapat memengaruhi persepsi, terlebih dalam pembagian pola pikir sakral dan sekular (Laughlin, 1989). Pada umumnya gereja memiliki tiga jabatan utama dalam organisasi (pendeta, bendahara, dan jemaat). Hasil penelitian Kistler (2008) menunjukkan bahwa pendeta akan lebih cenderung memiliki persepsi bahwa pengendalian internal tidak begitu penting. Persepsi dari anggota dalam organisasi adalah salah satu faktor yang menentukan karena dari persepsi ini akan membentuk penilaian dari individu atas suatu hal (Wang, 2007). Persepsi individu tersebut akan berpengaruh terhadap tingkat kekuatan pengendalian internal dalam suatu organisasi.

Hal tersebut selaras dengan belief pendeta yang cenderung berada pada ranah sacred (sakral). Kistler (2008) menemukan persepsi yang berbeda pada jabatan bendahara dan jemaat yang lebih cenderung memiliki belief yang secular (sekuler) dan memiliki persepsi bahwa pengendalian internal adalah sesuatu yang penting dalam pengelolaan keuangan gereja. Berdasarkan uraian tersebut dapat diturunkan hipotesis sebagai berikut:

Hipotesis 1: Terdapat perbedaan persepsi tentang pengendalian internal di antara pendeta, bendahara, dan jemaat.

Menurut Jacobs (2005) penerapan pengendalian internal masih menjadi perdebatan dalam lingkungan gereja. Perbedaan pendapat tersebut menurut Jacobs harus diuraikan dengan melihat berbagai faktor-faktor yang memengaruhi, salah satunya adalah besarnya uang persembahan yang diterima oleh gereja. Jumlah persembahan yang diterima oleh gereja terkait erat dengan masalah materialitas. Materialitas adalah pengaruh hasil nilai yang dihilangkan atas tingkat kepercayaan 
laporan keuangan. Penelitian sebelumnya yang dilakukan oleh Kistler (2008) menunjukkan bahwa semakin besar uang yang dikelola, semakin besar kecenderungan untuk menerapkan pengendalian internal. Hasil penelitian Kistler (2008) tersebut akan diujikan dalam penelitian ini. Atas dasar penjelasan tersebut, dirumuskan hipotesis:

Hipotesis 2: Jumlah persembahan memiliki hubungan positif dan signifikan dengan persepsi individual (anggota gereja) terhadap pengendalian internal.

Mendasarkan pada uraian dan hipotesis di atas dapat digambarkan model penelitian sebagai berikut:

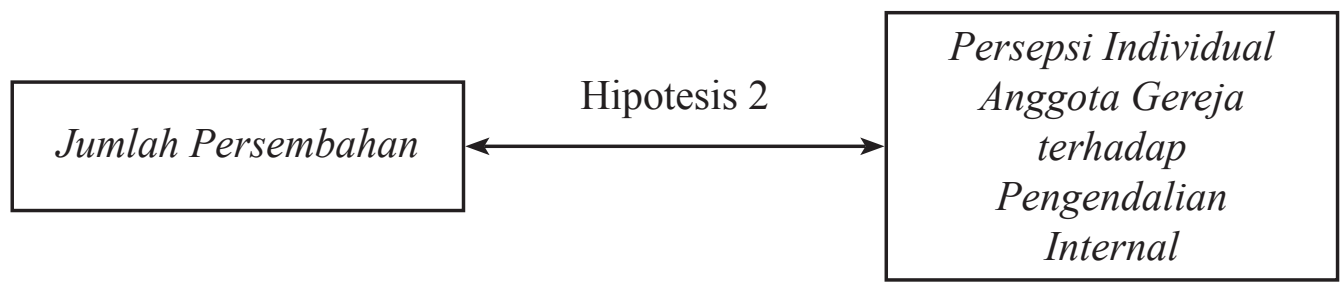

Gambar 2. Model Penelitian

\section{METODE PENELITIAN}

Penelitian ini dilakukan dengan menggunakan desain penelitian konfirmatori dan pengujian hipotesis dengan metode survei. Penelitian ini menggunakan data primer, yaitu data yang berisi informasi yang didapat langsung oleh peneliti sesuai dengan variabel-variabel yang digunakan untuk mencapai tujuan spesifik dari penelitian. Jangka waktu pengambilan data pada satu titik waktu tertentu (cross section). Selain itu penelitian ini juga menggunakan data sekunder, yaitu catatan-catatan gereja yang relevan bagi penelitian ini.

Penelitian ini menggunakan dua variabel, yaitu perkiraan rata-rata jumlah persembahan tiap bulan dan persepsi individual terhadap pengendalian internal untuk menjelaskan fenomena penerapan pengendalian internal di lingkungan gereja. Responden adalah anggota gereja (pendeta, bendahara, dan jemaat). Pemilihan sampel dalam penelitian ini menggunakan metoda purposive sampling, yaitu memilih responden dengan kriteria tertentu agar sesuai dengan tujuan penelitian. Kriteria yang digunakan adalah anggota gereja aktif dalam hal ini majelis (pendeta dan majelis bidang penatalayanan) dan jemaat biasa yang telah menjadi warga gereja minimal tiga tahun dengan pertimbangan warga tersebut telah mengenal seluk beluk tentang organisasi gerejanya. 
Pengumpulan data dilakukan dengan metode survei, yaitu mengirimkan kuesioner kepada ketiga kategori responden, yaitu pendeta, bendahara, dan jemaat. Kuesioner yang dikirimkan sebanyak 150 eksemplar pada 30 gereja di lingkungan sinode gereja pendukung Universitas Kristen Duta Wacana dan satu gereja dari luar pendukung Universitas Kristen Duta Wacana. Kuesioner yang kembali sebanyak 104 (response rate 69,33\%) dan 8 kuesioner tidak dapat digunakan karena tidak lengkap, sehingga dalam penelitian ini menggunakan 96 responden (use rate 64\%). Kuesioner dikirimkan langsung oleh peneliti kepada gereja-gereja yang bersangkutan dan dikonfirmasi kembali oleh peneliti melalui contact person yang dapat dihubungi setelah dua minggu kuesioner diterima oleh kantor gereja. Kuesioner terdiri dari dua bagian. Bagian pertama berisi profil responden dan data tentang kondisi gereja. Bagian kedua berisi persepsi responden terhadap pengendalian internal dengan nilai respon 5 skala Likert. Adapun profil responden seperti tertera dalam tabel 1 di bawah ini:

Tabel 1. Profil Responden

\begin{tabular}{|c|l|c|c|}
\hline Profil & \multicolumn{1}{|c|}{ Keterangan } & Jumlah & Persentase \\
\hline \multirow{4}{*}{ Gereja } & Gereja Kristen Jawa & 27 & 87,2 \\
\cline { 2 - 4 } & Gereja Kristen Indonesia & 2 & 6,4 \\
\cline { 2 - 4 } & Gereja Kristen Muria Indonesia & 1 & 3,2 \\
\cline { 2 - 4 } & Huria Kristen Batak Protestan & 1 & 3,2 \\
\cline { 2 - 4 } & \multicolumn{1}{c}{ Jumlah } & $\mathbf{3 1}$ & $\mathbf{1 0 0 , 0}$ \\
\hline \multirow{3}{*}{$\begin{array}{c}\text { Posisi/ } \\
\text { Jabatan }\end{array}$} & Pendeta & 31 & 32,3 \\
\cline { 2 - 4 } & Jendahara & 34 & 35,4 \\
\cline { 2 - 4 } & Rata-rata & $\mathbf{9 6}$ & 32,3 \\
\hline \multirow{2}{*}{$\begin{array}{c}\text { Usia } \\
\text { Responden }\end{array}$} & 32 th & Minimum & Maksimum \\
\hline
\end{tabular}

Sumber: Hasil survei

Uji validitas dilakukan untuk menguji kesesuaian instrumen penelitian (item pertanyaan atau pernyataan) dengan konstruk yang akan diukur. Skala pengukuran disebut valid apabila melakukan apa yang seharusnya dilakukan dan mengukur apa yang seharusnya diukur (Sekaran, 2000: 207-208). Apabila skala pengukuran dinyatakan valid berarti alat ukur yang digunakan dalam penelitian ini sudah tepat. Pengujian validitas indikator penelitian berupa persepsi anggota gereja tentang pengendalian internal dilakukan dengan menggunakan metode confirmatory 
factor analysis dengan teknik principal component analysis dan varimax rotation. Ukuran tingkat validitas dinyatakan dengan skor loading factor. Menurut Hair et al. (2006:779), suatu indikator dinyatakan valid apabila memiliki skor loading factor $\geq 0,5$. Hasil uji statistik menunjukkan, dari 23 item pertanyaan hanya 14 item yang valid atau memenuhi loading factor $\geq 0,5$.

Pengujian reliabilitas dimaksudkan untuk mengukur konsistensi dan stabilitas skala pengukuran (Sekaran, 2000: 205-207). Semakin tinggi tingkat reliabilitas suatu alat pengukur akan semakin tepat alat pengukur tersebut. Pengujian reliabilitas dilakukan dengan alpha $(\alpha)$ Cronbach yang menunjukkan konsistensi instrumen mengukur konsep. Sebuah konstruk memiliki reliabilitas tinggi apabila terdapat interkorelasi yang tinggi karena mereka mengukur latent construct yang sama. Ketentuan pengukuran reliabilitas, yaitu jika nilai alpha $(\alpha)=$ kurang dari 0,6 dikatakan buruk, antara 0,6-0,7 dikatakan dapat diterima (Hair et al., 2006:778), dan lebih dari 0,8 disebut baik (Sekaran, 2000: 312). Hasil uji statistik menunjukkan bahwa nilai alpha Cronbach sebesar 0,903 artinya nilai reliabilitas adalah baik.

Hasil pengujian statistik Kruskal Wallis untuk hipotesis 1 menunjukkan nilai signifikansi sebesar 0,737 yaitu melebihi 0,05 , artinya hipotesis 1 yang menyatakan terdapat perbedaan persepsi tentang pengendalian internal di antara pendeta, bendahara, dan jemaat ditolak. Hasil pengujian menunjukkan bahwa tidak terdapat perbedaan persepsi tentang pengendalian internal di antara pendeta, bendahara, dan jemaat.

Hasil pengujian korelasi Pearson untuk hipotesis 2 menunjukkan nilai 0,071 dan uji signifikansi menunjukkan 0,494 artinya hubungan tidak signifikan karena melebihi 0,05. Hasil ini menunjukkan bahwa jumlah persembahan tidak signifikan berhubungan dengan persepsi individual (anggota gereja) terhadap pengendalian internal.

\section{DISKUSI}

Hasil pendekatan kuantitatif menunjukkan tidak terdapat perbedaan yang signifikan pada persepsi tentang pengendalian internal di antara pendeta, bendahara, dan jemaat. Ketiga anggota gereja tersebut mempunyai pemahaman yang hampir sama tentang peranan pengendalian internal dalam gereja dan mereka mempunyai kesadaran yang sama tentang arti penting pengendalian internal. Hal ini mempunyai arti bahwa pengendalian internal sudah dibutuhkan oleh gereja, namun belum dianggap sebagai sesuatu yang penting bagi perkembangan gereja. 
Alasan pengendalian internal belum dianggap penting atau mendesak karena dua hal, yaitu: kemungkinan anggota gereja (1) belum mengetahui/memahami, atau (2) jika sudah mengetahui/ memahami, maka terdapat faktor pandangan tentang pengendalian internal. Kemungkinan pertama disebabkan oleh belum atau tidak adanya anggota atau tenaga gereja yang mempunyai keahlian di bidang akuntansi atau manajemen (Rixon, Rois, dan Faseruk, 2014). Hal ini terlihat dari dokumen atau sistem pencatatan keuangan yang tidak/kurang teratur.

Kemungkinan kedua, terdapat persoalan perbedaan antara spiritual-nonspiritual dan sakral-sekular sebagai aspek dikotomi perlunya penggunaan sistem akuntansi di gereja (Rixon, Rois, dan Faseruk, 2014). Hasil penelitian Keister (1974) menyatakan bahwa masyarakat di negara maju cenderung berpola pikir sekular dan masyarakat di negara berkembang cenderung berpola pikir sakral. Penelitian ini dilaksanakan di negara Indonesia (tergolong negara berkembang) yang tentunya berbeda dengan negara maju dalam hal profesionalisme dan budaya. Dalam hal profesionalisme, di Indonesia belum memiliki regulasi khusus yang mengatur tentang pengendalian internal organisasi gereja, meskipun sudah ada ketentuan khusus yang diatur melalui masing-masing sinode gereja. Sebagai contoh, ketentuan pengendalian internal Gereja Kristen Jawa (GKJ) ditunjukkan dalam Tata Laksana Pasal 20 ayat 4 tentang Pengelolaan Kekayaan Gereja dan ayat 5 tentang Pengawasan dan Pemeriksaan. Hal ini terjadi di sinode-sinode gereja lainnya yang mengatur persoalan pengendalian internal pada Tata Laksana Organisasi Gereja.

Pembagian pemikiran sakral/spiritual dan sekular/nonspiritual menyebabkan adanya pembagian antara ajaran gerejawi yang merupakan legitimasi gereja dan kehidupan gereja dan hal-hal yang berasal dari luar gereja atau duniawi (Booth, 1993). Meskipun Booth (1993) tidak menyatakan secara jelas tentang pemisahan tersebut, pengendalian internal sebagai bagian dari sistem akuntansi dianggap sebagai aspek sekular atau duniawi.

Perbedaan budaya dan pola pikir jemaat kemungkinan menjadi faktor yang membedakan, di mana gereja pada negara maju memiliki kecenderungan untuk berpikir secara logis, sedangkan pada negara berkembang menjunjung sakralisasi, sesuai dengan observasi yang dilakukan oleh Muller (2015). Dari sisi budaya, di Indonesia masih melekat budaya "sungkan" membicarakan pengelolaan keuangan gereja. Rasa sungkan terjadi karena alasan lebih condong pada spiritualitas dan kesakralan gereja sebagai institusi yang suci. Aspek pengendalian internal dianggap belum penting dan mendesak bagi kehidupan bergereja. Hasil penelitian Cornell, Johnson, dan Schwartz, Jr. (2013) menemukan bahwa para jemaat gereja secara umum mempercayai para pemimpinnya mengelola keuangan secara terbuka. Meskipun laporan keuangan gereja jarang disosialisasikan 
dan tidak seragam di antara gereja, defisit keuangan tampaknya tidak mengubah keyakinan para jemaat pada gereja. Mereka tetap mempercayai bahwa persembahan digunakan oleh gereja secara tepat. Cornell et al. (2013) juga menemukan bahwa para pastor secara konsisten mempercayai karyawan gereja dan yang mengelola keuangan gereja. Sebanyak 63\% pastor lebih meletakkan pada konsep kepercayaan daripada menyebarkan efektivitas pengendalian internal.

Hasil penelitian Cornell et al. (2013) mengisyaratkan gereja sebaiknya lebih banyak memikirkan tentang pengajaran dan pertumbuhan iman jemaat daripada aspek yang berkaitan dengan duniawi. Orientasi pemikiran duniawi cenderung akan menimbulkan konflik, karena konflik masih dianggap sebagai faktor disfungsional dan tabu dilakukan di gereja. Oleh karena itu membicarakan tentang akuntansi dan pengendalian internal gereja sebaiknya dikesampingkan agar tidak menimbulkan kecurigaan (1 Tim. 6:3-8) dan perpecahan dalam tubuh gereja.

Hasil temuan hipotesis 2 bahwa jumlah persembahan tidak memiliki hubungan yang signifikan dengan persepsi individual (anggota gereja) terhadap pengendalian internal, mempunyai makna bahwa anggota gereja memiliki kecenderungan kurang peduli atas pengendalian internal gereja. Terdapat anggapan dari anggota gereja bahwa sistem keuangan gereja dan pengendalian internal sudah berjalan dengan baik.

Terdapat asumsi bahwa, keyakinan akan kesakralan berdasarkan pemahaman bahwa anggota gereja tidak akan berani bertindak menyalahgunakan wewenang dan menguasai aset gereja yang notabene milik Tuhan. Dalam wawancara dan percakapan, beberapa anggota gereja meyakini bahwa apabila seseorang melakukan fraud pada persembahan, maka Tuhan sendiri yang akan mendatangkan hukuman seperti yang terjadi pada Hofni dan Pinehas (1 Sam. 2:1-36) dan Ananias dan Safira (Kis. 5:1-11). Terdapat kecenderungan berpendapat bahwa kejujuran pengelolaan aset gereja dikembalikan pada hati nurani masing-masing pribadi dan pertanggungjawaban langsung kepada Tuhan.

Selain itu, tampaknya konsep pengendalian internal kurang aplikatif di organisasi gereja. Menurut Jacobs (2005), penerapan sistem akuntansi yang ketat tidak dapat diterapkan oleh gereja, karena faktor dasar kepercayaan. Persembahan atau donasi yang diberikan kepada gereja bukan merupakan investasi, namun diberikan secara ikhlas dan anonim, sehingga kemungkinan memunculkan blind trust atas pengelolaan dana gereja. Persembahan ditujukan kepada Tuhan dan Tuhanlah yang mengetahui kesungguhan kita menjalankan kewajiban kita dengan Tuhan sesuai Alkitab. Jemaat tidak perlu memusingkan diri atas peruntukan persembahan tersebut dan memberi kepercayaan pada pengelola keuangan gereja. Berdasarkan hasil wawancara, para anggota gereja mendasarkan pada cara pemberian persembahan secara benar dan dilandasi oleh azas kesukarelaan, seperti tertulis dalam Alkitab, "Hendaklah masing-masing memberikan menurut kerelaan hatinya, 
jangan dengan sedih hati atau karena paksaan, sebab Allah mengasihi orang yang memberi dengan sukacita" (2 Kor. 9:7).

Selain itu, hasil wawancara menunjukkan bahwa anggota gereja melandasi diri pada pemahaman yang berasal dari Matius 6:1-4. Dalam memberikan sedekah (atau persembahan) tidak perlu diketahui orang lain atau tidak dipamerkan (Mat. 6:1). Kita harus melupakan persembahan/ sedekah dan tidak terus menerus membicarakan, apalagi membanggakan diri atas perbuatan murah hati yang kita lakukan. Dalam memberikan persembahan jangan menarik perhatian orang lain agar tidak jatuh dalam perangkap dosa untuk mendapatkan pujian dari orang lain (Mat. 6:2-3).

Temuan penelitian ini berbeda dengan hasil penelitian Kistler (2008). Temuan Kistler (2008) menyatakan bahwa jumlah persembahan yang diterima oleh gereja memiliki hubungan yang positif dan signifikan dengan persepsi individu tentang pengendalian internal. Hal ini menunjukkan bahwa semakin besar jumlah persembahan semakin tinggi persepsi individu terhadap pengendalian internal. Penelitian ini dilakukan pada gereja-gereja di negara maju yang memiliki regulasi khusus atas keuangan tempat ibadah yang dapat diartikan bahwa jumlah persembahan yang semakin meningkat juga memerlukan peningkatan kualitas pengelolaannya. Pendapat Kistler (2008) relevan dengan Lukas 16:10-11, "Barangsiapa setia dalam perkara-perkara kecil, ia setia juga dalam perkara-perkara besar. Dan barangsiapa tidak benar dalam perkara-perkara kecil, ia tidak benar juga dalam perkara-perkara besar. Jadi, jikalau kamu tidak setia dalam hal Mamon yang tidak jujur, siapakah yang akan mempercayakan kepadamu harta yang sesungguhnya." Ayat ini mengandung arti bahwa persembahan gereja yang berwujud harta duniawi (material) merupakan representasi harta surgawi (kekudusan) yang harus dijaga. Tetapi dalam penerapannya gereja tidak begitu mementingkan tata cara untuk menjaga harta duniawinya, terbukti dengan tidak semua gereja memiliki unsur penting dalam pengendalian internal keuangan, yaitu bagian audit internal, tetapi cukup dengan melakukan verifikasi saja.

Hasil wawancara terstruktur yang dilakukan pada responden menunjukkan bahwa terdapat suatu hal yang membedakan gereja dengan organisasi nonprofit lainnya dalam hal pengendalian internal, yaitu jika terjadi penyimpangan keuangan maka gereja lebih cenderung melakukan tindakan yang persuasif berupa penggembalaan khusus. Mengacu pada pendapat McNeal (2006) yang menyatakan bahwa salah satu unsur dalam pengendalian internal dan merupakan faktor kunci adalah adanya reward and punishment sulit untuk dilaksanakan karena tidak masuk dalam hukum positif, dan kecenderungan keyakinan kesakralan akan menyerahkan sesuai dengan hukum Tuhan. Pendapat tersebut didukung oleh hasil wawancara, baik jemaat gereja, bendahara gereja, dan pendeta. 
Menurut pendapat salah satu pendeta, persembahan dianggap milik Tuhan dan Tuhanlah yang berhak memberi sangsi pada orang yang menyalahgunakan milikNya. Sanksi tersebut lebih didasarkan pada kepekaan subjektif atau "iman". Hasil wawancara dengan seorang pendeta dan seorang bendahara menunjukkan hasil yang sama, yaitu ranah hukum positif dapat membantu penerapan pengendalian internal, namun membawa kasus terjadinya penyimpangan keuangan dalam gereja ke dalam hukum positif berpotensi menimbulkan "biaya" yang lebih besar daripada dengan menyelesaikannya secara kekeluargaan. Biaya tersebut termasuk pengorbanan kehilangan roh "pengampunan" dan seolah gereja sebagai sebuah "korporat" yang lebih mementingkan sisi kelangsungan hidup organisasi secara duniawi. Padahal, Tuhan Yesus menaruh perhatian dengan mencari domba-domba yang hilang dan tersesat (Luk. 15:1-7).

\section{SIMPULAN, KETERBATASAN, DAN SARAN}

\section{Simpulan}

Hasil uji hipotesis 1 menunjukkan tidak terdapat perbedaan yang signifikan persepsi tentang pengendalian internal di antara anggota gereja (pendeta, bendahara, dan jemaat). Para anggota jemaat mempersepsikan bahwa pengendalian internal diperlukan oleh organisasi gereja, namun belum terlalu mendesak atau penting. Anggapan penting atau tidaknya pengendalian internal tersebut dapat disebabkan bahwa gereja adalah organisasi sosial keagamaan yang didirikan bersifat sukarela sehingga tidak tepat jika sistem pengendalian internal seperti di organisasi bisnis diterapkan di gereja.

Hasil uji hipotesis 2 menunjukkan bahwa jumlah persembahan tidak memiliki hubungan yang signifikan dengan persepsi individual (anggota gereja) terhadap pengendalian internal. Hasil temuan ini menunjukkan kecenderungan para anggota gereja untuk tidak mempersoalkan peruntukan persembahannya. Para anggota gereja mempercayakan sepenuhnya pengelolaan persembahan kepada pengurus gereja. Penjelasan secara lebih spesifik kondisi manajemen gereja di Indonesia pada umumnya mengesampingkan unsur profesionalisme dan lebih menekankan pada hubungan baik antar anggota jemaat (Kuntadi, 1995). Selain masalah hubungan baik, juga sedikit banyak dipengaruhi oleh budaya "sungkan" dalam tata cara pergaulan antar sesama dan cenderung akan memilih untuk tidak peduli dalam hal keuangan di tempat ibadah (Sasongko, 2012). Temuan ini selaras dengan Hardy dan Ballis (2013) yang menyatakan bahwa akuntabilitas di gereja lebih cenderung untuk memenuhi formalitas daripada untuk mendukung pengendalian 
internal, sehingga kualitas laporan keuangan gereja masih membutuhkan pengujian untuk kualitas laporan keuangan tersebut. Penjelasan lain dalam tidak ada hubungan yang signifikan antara jumlah persembahan dengan persepsi individual terhadap pengendalian internal adalah bahwa lebih mudah melakukan kendali atas jumlah uang yang kecil daripada jumlah uang yang besar. Kaitannya dengan persembahan adalah lebih mudah jika persembahan gereja dalam jumlah yang lebih kecil, maka akan lebih mudah dalam melakukan penelusuran jika terjadi fraud. Penjelasan lain adalah dari data kualitatif rata-rata menunjukkan bahwa narasumber sudah percaya bahwa keuangan gereja telah dikelola dengan baik, meskipun terdapat sedikit skeptisme terhadap kualitas laporan keuangan gereja.

\section{Keterbatasan dan Saran}

Penelitian ini memiliki beberapa keterbatasan. Pertama, responden terbatas pada anggota gerejagereja sinode pendukung Universitas Kristen Duta Wacana, yang berada di wilayah Yogyakarta dan sekitarnya, sehingga mengakibatkan rendahnya generalisasi hasil penelitian. Kedua, instrumen kuesioner yang digunakan dalam penelitian ini adalah instrumen pengendalian internal untuk organisasi profit (Kistler, 2008). Ketiga, pengisian kuesioner oleh responden tidak luput dari bias kepatutan sosial (social desirability bias).

Berdasarkan keterbatasan di atas, kami mengusulkan saran-saran untuk perbaikan dan pengembangan penelitian ini dapat dijabarkan sebagai berikut:

1. Menambah jumlah responden dan memperluas cakupan penelitian pada gereja yang menjadi sinode pendukung maupun bukan pendukung Universitas Kristen Duta Wacana, Yogyakarta.

2. Merumuskan konstruk dalam bentuk instrumen-instrumen penelitian yang lebih tepat untuk organisasi nonprofit bidang keagamaan.

3. Memperbaiki instrumen penelitian untuk mengurangi bias kepatutan sosial.

4. Pengembangan penelitian lanjutan dapat kepada tema-tema lain terkait akuntansi gereja, misalnya: pengukuran kinerja gereja.

5. Observasi secara lebih mendalam dapat dilakukan pada tiap-tiap gereja yang berpotensi untuk menemukan keunikan pengendalian internal terkait kondisi gereja-gereja Kristen Protestan yang berbeda-beda satu dengan yang lain. 


\section{DAFTAR PUSTAKA}

Blackwood, A.S. 2012. The Nonprofit Sector in Brief: Public Charities, Giving, and Volunteering. Urban Institute.

Booth, P. 1993. "Accounting in Churches: A Research Framework and Agenda". Accounting, Auditing and Accountability Journal, 6 (4).

Commission on Private Philanthropy and Public Needs. 1975. Giving in America: Toward a Stronger Voluntary Sector: Report on the Commission on Private Philanthropy and Public Needs. Washington, DC.

Cornell, R.M., Johnson, C.B., dan Schwartz, Jr., W.C. 2013. “Influence of Leadership Positions on Internal Controls and Reported Fraud in Religious Organizations". Journal of Forensic \& Investigative Accounting. 5 (1): 85-125.

COSO. 1992. Internal Control-An Integrated Framework. The Committee of Sponsoring Organizations of the Treadway Commission.

Duncan, J.B., dan Flesher, D.L. 2002. "Does Your Church Have Appropriate Internal Control for Cash Receipts?" The National Public Accountant, 15-20.

Ellis, L.O. 1974. "Internal Control for Churches and Community Organizations". The CPA Journal, 44(5): 45-8.

Hair, J.F. Jr., Black, W.C., Babin, B.J. Anderson, R.E., dan Tatham, R.L. 2006. Multivariate Data Analysis. $6^{\text {th }}$ ed. New Jersey: Prentice Hall.

Holtfreter, K. 2004. "Fraud in US Organizations: An Examination of Control Mechanisms". Journal of Financial Crime, 12 (1): 88-95.

Jacobs, K. 2005. "The Sacred and the Secular: Examining the Role of Accounting in the Religious Context." Accounting, Auditing and Accountability Journal, 18 (2): 189-210.

Keister, O.R. 1974, January. "Internal Control for Churches”. Management Accounting, 557 (7): 40.

Keller dan Owens. 2015. "Financial Internal Controls in Heartland Churches: A Survey Report. https://www.kellerowens.com/wp-content/uploads/2015/12/Financial-Internal-Controlsin-Churches-A-Survey-Report-.

Kistler, D.S. 2008. "Examining the Prostestant Church's Financial Environment, Internal Controls, and Financial Integrity”. Dissertation. Prescott Valley, Arizona: Northcentral University.

Kuntadi, S. 1995. "Profesionalisme dalam Gereja". Penuntun, 1 (3): Universitas Negeri Malang. 
Laughlin, R. 1984. The Design of Accounting System: A General Theory with an Empirical Study of the Church of England. Unpublished Ph.D. Thesis, University of Sheffield. . 1989. "Accounting in Its Social Context: An Analysis of the Accounting Systems of the Church of England". Accounting, Auditing, and Accountability Journal, 1 (2): 19-42. . 1990. "A Model of Financial Accountability and the Church of England". Financial Accountability and Management, Summer 1990 Vol. 6 (2): 93-114.

Midkitt, K.A. 2004. "Catch the Warning Signs of Fraud in NPOs". Journal of Accountancy, 197 (1): 28 .

Muller, R. 2015. "Incarnation Theology versus the Sacralisation of Authority. AOSIS. South Africa.

Myers, D. 2012. "External Stakeholders and Internal Controls in Churches". Accounting Undergraduate Honors Theses. 2. http://scholarworks.uark.edu/acctuht/2.

Prentice, K.B. 1981. "Church Accounting: Good Intentions and Good Accounting”. The Woman CPA, 43 (2), 8-14.

Rixon, D., Rois, J., dan Faseruk, A. 2014. “The Seven Deadly Sins of Church Accounting”. Journal of Business Diversity. 14 (1): 9-17.

Sasongko, G. 2012. Faham Keselamatan dalam Budaya Jawa. Yogyakarta: Ampera Utama.

Sekaran, U. 2000. Research Methods for Business, $3^{\text {rd }}$ Ed. New York: John Wiley \& Sons Inc.

Synder, H., dan Clifton, J. 2005. "Stealing from the Collection Plate". Fraud Magazine, 19 (6): 21.

Ventura, M., dan Daniel, S. 2010. "Opportunities for Fraud and Embezzlement in Religious Organizations: An Exploratory Study". Journal of Forensic \& Investigative Accounting, 2 (1): 1-35.

Wang, Y. 2013." On the Cognitive Processes of Human Perception with Emotions, Motivations and Attitudes". International Journal of Cognitive Informatics and Natural Intelligence, 4: $1-13$.

West, R., dan Zech, C. 2007. "Internal Financial Controls in the U.S. Catholic Church". Research study of the Villanova University Center for the Study of Church Management, January 2007. http:/www.villanova.edu/business/assets/documents/excellence/church/ catholicchurchfinances.pdf. Diakses 4 Juni 12.

Wilson, B. 1967. Patterns of Sectarianism. London: Heinemann. .2004. Alkitab. Jakarta: Lembaga Alkitab Indonesia. 
. 2005. Himpunan Pokok-Pokok Ajaran Gereja, Tata Gereja dan Tata Laksana, Pertelaan, Peraturan Pembimbingan dan Ujian Calon Pendeta, Peraturan Kesejahteraan Pendeta dan Karyawan. Sinode Gereja-gereja Kristen Jawa.

http://www.gkj.or.id/klasis. Diakses 15 September 2015.

http://www.jawaban.com/read/article/id/2013/02/20/90/130220181544/Pihak-Abraham-AlexTanuseputra-Tanggapi-Tuduhan-Penggelapan-Uang-Gereja. Diakses 13 Mei 2015. 